Volume 9. No. 8, August 2021

International Journal of Emerging Trends in Engineering Research

Available Online at http://www.warse.org/IJETER/static/pdf/file/ijeter22982021.pdf

https://doi.org/10.30534/ijeter/2021/22982021

\title{
A Review of Innovation in Cocoa Bean Processing By-Products
}

\author{
Rossi Indiarto ${ }^{1}$, Zaidhiya Rizqi Raihani ${ }^{2}$, Mega Puspita Dewi ${ }^{3}$, Zsahra Raisa Aqila ${ }^{4}$, \\ Muhammad Yusuf Efendi ${ }^{5}$ \\ Department of Food Industrial Technology, Faculty of Agro-Industrial Technology, Universitas Padjadjaran, \\ Jl. Raya Bandung-Sumedang Km. 21, Jatinangor, Sumedang, 45363, Indonesia \\ ${ }^{1}$ rossi.indiarto@unpad.ac.id; ${ }^{2}$ zaidhiya17001@ mail.unpad.ac.id; ${ }^{3}$ mega17011@ mail.unpad.ac.id; \\ ${ }^{4}$ zsahra17001@mail.unpad.ac.id; ${ }^{5}$ myusufe48@gmail.com
}

\begin{abstract}
Although cocoa production generates numerous by-products, only $10 \%$ of cocoa pods are used commercially, with the remaining $90 \%$ discarded. Cocoa processing generates by-products such as pod husks, pulp, and bean shells. It can recycle as a result of its high fiber and bioactive compounds Cocoa-pods produce additional dietary fiber, wrinkle-reducing cosmetics and preservatives, animal feed, organic fertilizers, raw materials for paper-making, and biofuels. Sugar, minerals, fat, and protein are abundant in the pulp. The cocoa pulp can be used to make various beverage products, including mixed drinks with added fruits, kefir beverages, wine, soft drinks, marmalade, and vinegar. Because of its high content of lignin, cellulose, protein, fat, carbs, and polyphenols, the cocoa bean shell is an excellent source of dietary fiber. It contains a high fiber content and has a high resale value when used as a renewable energy source. This review article will discuss the management of cocoa by-products and value-added products with various applications.
\end{abstract}

Key words: By-product, catechin, cocoa, eco-friendly, husk, cellulose

\section{INTRODUCTION}

There are twenty recognized cacao (Theobroma cacao L.) varieties, but these are the three most popular. It is available in the Criollo, Forastero, and Trinitario varieties. Numerous by-products are produced throughout the cocoa manufacturing process. However, only $10 \%$ of the entire weight of cocoa pods is utilized economically, with the other $90 \%$ thrown as waste [1]. The amount of waste generated creates economic difficulties and may contribute to environmental pollution. As a result of population growth and the threat of raw material depletion, extensive reuse of waste materials that are still useful is being undertaken. Cocoa processing can reuse by-products due to the high fiber content and bioactive compounds found in cocoa [2], [3]. Bioactive components are substances found in trace amounts in foods that have been shown to benefit human health [4].

Cocoa by-products are produced during cocoa bean processing. The cocoa beans are separated from their pod husks and fermented then dried for storage and transportation. The pod husk, pulp, and bean shell make up about $70-80 \%$ of the dry weight of cocoa pods [5]. The three waste products are considered trash because they might create environmental issues like smells or disease transmission to neighboring plants [6]. The major by-product of cocoa bean processing is the bean shell. Ninety-eight grams of cocoa bean shell can be obtained from one kilogram of cocoa beans. This skin is typically separated from the cotyledons before and after roasting [7], [8]. Cocoa bean shells comprise $10 \%$ to $17 \%$ of the total weight of cocoa beans [9]. The percentage varies depending on how the cocoa beans are fermented [7].

Cocoa pod husks are obtained after the cocoa beans have been collected from the cocoa pod. The husk of the cocoa pod contributes to roughly 52-76\% of its weight. Cocoa pod husks are widely used in animal and poultry feed due to their protein content (5.9-9.1\%), fiber content (22.6-35.7\%), and fat content (1.2-10\%) [10]. Cocoa pod husks are composed of three distinct layers, i.e., pericarp, mesocarp, and endocarp. There are various colors, ranging from green in the Forastero species to red in Criollo species to mixed colors in Trinitario and Forastero-Criollo hybrids. It corresponds to the color of the exocarp. The thickness of the fruit's skin varies depending on how mature it is [11].

The cocoa pulp is the white mucus that coats the beans inside the cocoa pod. The pulp is typically sweet in flavor and can contribute color, taste, and aroma to the fermentation process by incorporating various microorganisms [12]. The pulp is a rich source of sugar, minerals, lipids, and protein. Cocoa pulp contained $3.12 \%$ fat and $3-5 \%$ protein. The pulp has a $\mathrm{pH}$ of 3.78 due to acetic and lactic acid [13]. This review discusses cocoa by-product management and product development with applications in various fields.

\section{COCOA POD HUSKS}

Pod husks are a by-product of the cocoa production process. Following cocoa bean separation, the pod husk is typically removed and used as organic fertilizer. However, leaving untreated cocoa pods on the soil surface can result in 
plant diseases such as black rot on fruit caused by Phytophthora sp. [14]. Cocoa pod husks are primarily composed of fiber. It contains $19.7-26.1 \%$ cellulose in the mesocarp, $8.7-12.8 \%$ hemicellulose in the epicarp, $14-28 \%$ lignin in the epicarp, and $6-12.6 \%$ pectin in the endocarp [15]. Cocoa pod husks also contain between 32-47\% carbohydrates, $7-10 \%$ protein, and $1.5-2 \%$ fat. Additionally, minerals such as potassium, calcium, magnesium, phosphorus, sodium, and iron are present [16], [17].

Due to the high content of cocoa pod husks, bioconversion of its value-added products is exceptionally high. However, cocoa pod husks as a renewable resource are still underutilized. The following are some of the applications and potential value-added products for cocoa pod husks.

\subsection{Dietary fiber supplementation}

Cocoa pod husks are high in fiber. It contains a variety of dietary fibers, both soluble and insoluble. The pectin, -glucan, oligosaccharides, and some hemicellulose comprise soluble dietary fiber. Additionally, insoluble dietary fiber contains lignin, cellulose, and hemicellulose [18]. Pectin is the most abundant component in cocoa pod husks [19]. Pectin is an essential component in food products because it may create a gel, which enhances texture and stability [20]. The $\mathrm{pH}$, time, and temperature are the primary variables that influence pectin's extraction process and physicochemical properties [14]. Pectin can be dissolved in water, hydrochloric acid, nitric acid, or citric acid [21], [22]. The development of foods containing soluble dietary fiber can benefit individuals deficient in dietary fiber or suffer from anorexia. Soluble dietary fiber can help the body retain water, sustain a sense of fullness after eating, and reduce glucose absorption in the small intestines [23]. The large intestine ferments soluble dietary fiber that cannot be digested in the small intestine. Soluble dietary fiber from cocoa pod husks has been added to muffins and bread manufacturing. Soluble dietary fiber has been shown to influence both texture and organoleptic properties [24].

Additionally, cocoa pod husks contain 52-74\% insoluble dietary fiber. Within the digestive system, insoluble dietary fiber acts as a laxative. They make high-fiber bread by substituting cocoa pod husk powder for wheat flour, resulting in a denser and harder texture. It demonstrates how fiber during processing affects the texture and quality [24]. The food industry is required to maintain a healthy balance of soluble and insoluble dietary fibers [25]. As a result, pretreatment, such as acid hydrolysis, is required to balance the two fibers. Insoluble fiber content is more significant than soluble fiber content. Acid hydrolysis can distribute uronic acid inside the insoluble dietary fiber and enhance soluble dietary fiber [26]. The addition of cocoa pod husk powder to food remains a challenge due to the community's varied acceptance, even though its inclusion in food processing promises improved food quality.

\subsection{Cosmetic antiwrinkle agents and natural preservatives}

Cocoa pod husks may be an antioxidant source due to their phenolic content. Some of the active phenolic compounds in cocoa pod husks are catechins, epicatechin, quercetin, and gallates [27]. Cocoa pod husks have a greater antioxidant capacity than cocoa bean shells, cocoa pulps, or tomato rinds [6].Cocoa pod husks must first be dried to ensure the content's stability before further processing. Many methods are utilized to dry the products, such as hot air drying, microwave drying, and freeze-drying. Specific drying techniques may affect the phenolic content due to changes in the microstructure [27]. The phenolic compounds found in cocoa pod husks were extracted with organic solvents. The efficiency of extraction is dependent on the chemical composition of the organic solvent used. Due to the effect of different solubility, the phenolic content extracted with acetone and methanol yielded significantly higher yields than when extracted with ethanol [6].

Cocoa pod husk extract is used in cosmetics as an antiwrinkle agent. It applied a gel containing cocoa pod peel extract to adult human skin for 3-5 weeks. The results indicate that cocoa pod husk extracts can significantly reduce wrinkles while also hydrating the skin [28]. Additionally, supercritical pod husk extracts may be used as natural antioxidants in food. This antioxidant compound acts as a natural preservative, prolonging food shelf life [11].

\subsection{Animal feed}

Cocoa pod husk is also utilized as cattle fodder. It aims to reduce conventional corn and bran-based feed while also lowering the feed cost [29]. Research is still needed to ascertain its effect on the digestive system of animals. Cocoa pod husks contain 14\% lignin, 11\% hemicellulose, 35\% cellulose, and $6 \%$ pectin [30]. Animals with a monogastric stomach, such as pigs and rabbits, are unable to digest hemicellulose. It is because enzymes capable of hydrolyzing hemicellulose are not readily available [31]. Pretreatment actions include the addition of viscozyme and pectinex enzymes and Phanerochaete chrysosporium fungi, which can boost the digestibility of cocoa pods by up to $30 \%$ [32].

\subsection{Organic fertilizer}

Due to the high mineral content of cocoa pod husks, they can substitute conventional fertilizers with cocoa pod husk fertilizers. Minerals are critical for plant growth. Minerals as micronutrient components perform various functions, including supplying nutrients to plants, activating various enzymes, and protecting potential electrical gradients in cell membranes. Minerals assist the cells in maintaining a balance of anions and cations. Additionally, minerals regulate turgor, osmotic pressure and are responsible for water distribution throughout the plant [33].

Combining cocoa pod husk powder with phosphorus fertilizer has improved crop quality, seed yield, and yield index compared to NPK fertilizer alone [34]. Pod husk powder may also affect tomato fruit growth, yield, and soil fertility. This environmentally friendly application can replace the use of expensive and less eco-friendly NPK fertilizers. Burning cocoa pod husks also produces ash, improves agricultural sanitation, and controls black rot disease sources [35]. 
Rossi Indiarto et al., International Journal of Emerging Trends in Engineering Research, 9(8), August 2021, 1162 - 1169

\subsection{Paper-making}

Paper is typically made from tree wood fibers. Cocoa pod husks may be a solution to global warming and alternative energy research. To extract the pulp, first, dissolve the fruit peel in an alkaline solution at a high temperature. Pulp quality is determined by lignocellulose content, with more cellulose, lower lignin, and lower ash desired [36]. Surface morphology, fiber characteristics such as length, diameter, lumen width, and thickness affect paper quality. Teabags are typically made from pulp with thinner and shorter fibers, whereas writing paper is made from pulp with more robust and thicker fibers [37].

\subsection{Biofuels}

Cocoa pod husks are rich in lignocellulosic material. It can be converted to bioethanol. Because cocoa pod husks have less carbohydrate than corn cobs and rice straws, they produce less bioethanol. Cocoa pod husks contain more lignin than corn cobs and rice straw [15], [38].

Pretreatment methods to remove lignin from lignocellulosic biomass are essential for biofuel production. Physical, chemical, and biological treatments were all used as pretreatment measures. Chemical treatment utilizing acid or alkali extraction and organic solvents. While physical treatment using a steam explosion. The biological treatment was utilizing enzymatic hydrolysis [15].

Pretreatment can increase the hydrolysis susceptibility of hemicellulose and cellulose. It resulted in fermentable sugars and assimilated monosaccharides. Saccharomyces cerevisiae, Pichia stipites, and Kluyveromyces marxianus ferment lignocellulosic biomass to generate pentose and hexose sugars. [38]. Combining physical treatment methods such as steam explosion and enzymatic treatment is recommended to reduce energy and increase lignin separation efficiency [39].

It can also create bio-oil and biogas from cocoa pod husks. Bio-oil and biogas are made through the pyrolysis of cocoa pods in a 17.4-liter hot reactor operating at atmospheric pressure. Pyrolysis was performed at $300-600^{\circ} \mathrm{C}$. Bio-oil is the condensed fraction of volatile substances, while biogas is the non-condensable fraction [40]. Table 1. shows the numerous applications of cocoa pod husks.

Table 1. Utilization of cocoa pod husks

\begin{tabular}{lll}
\hline \hline Main compounds & Application & Ref. \\
\hline Pectin & $\begin{array}{l}\text { Reduce the amount of wheat } \\
\text { flour used in the production of } \\
\text { high-fiber bread }\end{array}$ & {$[24]$} \\
\hline Phenolic & $\begin{array}{l}\text { Anti-wrinkle ingredients in } \\
\text { cosmetics }\end{array}$ & {$[28]$} \\
\hline Phenolic & Food natural preservatives & {$[11]$} \\
\hline $\begin{array}{l}\text { Hemicellulose, } \\
\text { cellulose, lignin, } \\
\text { and pectin }\end{array}$ & Animal feed & {$[29]$} \\
\hline $\begin{array}{l}\text { Potassium, } \\
\text { calcium, } \\
\text { phosphorus }\end{array}$ & Ond &, \\
\hline
\end{tabular}

\begin{tabular}{lll}
\hline \hline Main compounds & Application & Ref. \\
\hline Lignocellulose & Basic paper-making material & {$[36]$} \\
& &, \\
& & {$[41]$} \\
\hline Lignocellulose & Biofuels & {$[38]$} \\
& &, \\
& & {$[40]$} \\
& & {$[42]$} \\
& &, \\
\hline Cellulose & Nanocrystalline & {$[43]$} \\
\hline Cellulose & Bioplastic film & {$[44]$} \\
\hline
\end{tabular}

\section{COCOA PULP (MUCILAGE)}

The fruit pulp/mucilage is another by-product of cocoa pods. The cocoa pulp is white and slimy outside because it comprises spongy parenchyma cells containing cell sap. The cocoa pulp can produce a slightly cloudy whitish liquid known as cocoa pulp juice or sweatings [10]. Based on Anvoh et al. [13], the physicochemical composition of cocoa pulp liquid was $85.30 \%$ water, $3.76 \%$ ash, $3.54 \%$ fat, $0.41 \%$ protein, and $16.17 \%$ total solids. The pulp liquid has a high level of acidity, where the $\mathrm{pH}$ ranges from 3.66-3.75. The pulp liquid included citric acid, malic acid, acetic acid, oxalic acid, lactic acid, fumaric acid, citric acid, fumaric acid, citric acid, and ascorbic acid at concentrations (mg/L) of 9.14; 3,6; $2.28 ; 1.27 ; 1.23 ; 0.02 ; 9.14$; and 18.3 respectively.

Meanwhile, the liquid waste contains $7.5 \%$ sugar. It comprises sucrose, glucose, and fructose with 107.6, 23.3, and $10.6 \mathrm{mg} / \mathrm{mL}$. Then, for the mineral content, potassium, sodium, phosphor, calcium, and magnesium had concentrations of $950,30.5,62.47,171.5$, and $82.5 \mathrm{mg} / \mathrm{L}$, respectively. Because of its composition, the cocoa pulp may be used to make beverages such as mixed drinks [46], kefir drinks [47], wine [48], and other products such as marmalade[13] and vinegar [49].

\subsection{Fruit juice mixed drinks}

The cocoa pulp contains significant minerals [46]. Still, it is deficient in vitamins, particularly vitamin C. Afolabi et al. [46] created a cocoa pulp drink product with fortified pineapple juice to supplement the nutritional content, particularly vitamin $\mathrm{C}$, to create a complete beverage product with nutrients. According to his research, the CP-PJ (Cacao Pulp-Pineapple Juice) mixed drink contains more calcium, iron, fat, and phosphorus but less protein, carbohydrates, and vitamin $\mathrm{C}$, with a higher cocoa pulp content $(\mathrm{PJ})$. The greater the concentration of cocoa pulp in the CP-PJ mixed drink, the lower the crude fiber content. It demonstrates that the mixed drink CP-PJ is an easily digestible beverage. The panelists gave the most favorable rating to the composition of $50 \%$ cocoa pulp (CP) and 50\% pineapple juice (PJ), 7.33.

\subsection{Kefir beverage}

Apart from fruit juices, the cocoa pulp can be fermented with kefir to create a fermented beverage. Kefir is a milk 
Rossi Indiarto et al., International Journal of Emerging Trends in Engineering Research, 9(8), August 2021, 1162 - 1169

beverage made from kefir grains that is acidic and alcoholic. It is like watered yogurt. Kefir originates in the Caucasus Mountains and comprises probiotic microorganisms suspended in a complex protein and polysaccharide matrix [50], [51]. Consumers regard kefir beverage products as healthy beverages. According to Nielsen et al. [52], kefir has gained widespread recognition as a beneficial probiotic. Hamida et al. [53] investigated the use of kefir and its by-products as antiviral agents. Puerari et al. [47] researched fermented drinks made from cocoa pulp-kefir beans that are healthy while also utilizing and developing cocoa pulp waste. Kefir beans were used as a starter culture in this study to make fermented cocoa beverage products. Inoculating kefir beans on cocoa pulp resulted in fermentation. For 48 and 72 hours, the fermentation process was carried out. During the 72-hour fermentation period, lactic acid concentrations, acetic acid, malic acid, propionic acid, and citric acid increased to their maximum values. The panelists approved the products fermented at $10{ }^{\circ} \mathrm{C}$ for 48 and 72 hours with 92 and $100 \%$ acceptance, respectively. It is due to the drink's low acidity and alcohol level. After 48 and 72 hours at $25^{\circ} \mathrm{C}$, it generated an alcoholic kefir drink. The acceptance value of the alcoholic kefir beverage is also relatively high, at about $80 \%$ among panelists.

\subsection{Wine}

Duarte et al. [48] investigated the production of alcoholic beverages from the cocoa pulp. It compared alcohol production from cocoa pulp, cupuassu, gabiroba, jaboticaba, and umbu pulp. Cocoa wine contains the most alcohol of all the alcohol compounds. Only cocoa wine $6.8 \mathrm{mg} / \mathrm{L}$ has the 2-heptanol ethyl ester group. However, 2-phenoxyethanol and 3-ethoxy-1-propanol are not present. Methanol concentrations $(\mathrm{mg} / \mathrm{L})$ in cocoa wine and jaboticaba were 195 and 181, respectively. It is very hazardous alcohol present in wine that must be controlled. Enzymes hydrolyze the methoxy pectin group during fermentation to generate methanol [48].

The most common wine acids are tartaric, malic, citric, lactic, and succinic. The acidity level of wine products can indicate the wine's quality [48], [54]. The concentrations $(\mathrm{g} / \mathrm{L})$ of malic, succinic, and acetic acids in cocoa wine were $0.29 ; 3.94$; and 0.37 , respectively. Malic acid contributes to the wine's acidity. It has two carboxylic acid groups, which release protons to the solution and make it more acidic. Succinic acid, produced during fermentation, gives a salty and bitter taste to wine [55]. Acetic acid with a concentration greater than $0.7 \mathrm{~g} / \mathrm{L}$ imparts the vinegar flavor and aroma. Ethyl esters such as ethyl lactate, diethyl succinate, diethyl malate, and mono-ethyl succinate are found in cocoa wine. According to Perestrelo et al. [51] and Duarte et al. [43], this group of ethyl esters contributes to overall wine quality and provides 'flowery' sensory attributes.

\subsection{Carbonated cocoa beverage}

Carbonated beverages are non-alcoholic beverages that have been carbonated. It is composed of water, carbon dioxide, and flavorings. Although there is no standard for carbonation in a carbonated beverage, it typically contains between 1 and 5 gas volumes (1.05-5.27 $\mathrm{kg} / \mathrm{cm}^{2}$ gas pressure) per liquid volume [56]. According to Randall et al. [56], the essential ingredients for carbonated beverages include water. It has been saturated with $\mathrm{CO}_{2}$, sweeteners, acid compounds (acetic, citric, fumaric, gluconic, Tartaric), flavors (derived from fruits, vegetables, leaves, and synthetic flavors), natural dyes, as well as preservatives, and other additives. Escalante et al. [57] cocoa soda beverage is made with a combination of chocolate paste and cocoa pulp in concentrations of 10 and 15 grams, mixed and heated at $71.1^{\circ} \mathrm{C}$ for 15 seconds. The filtered mixture added the carbon dioxide $\left(\mathrm{CO}_{2}\right)$ via a soda stream, and each beverage receives five pulses of $2 \mathrm{~g} \mathrm{CO}_{2}$. Randall et al. [56] state that the essential ingredients for carbonated beverages are water that has been saturated with $\mathrm{CO}_{2}$ gas. Each drink had a Brix degree of 13-15 and a $\mathrm{pH}$ of 4.5-4.6.

The raw material, chocolate paste, contains a higher concentration of minerals compared to cocoa pulp. Sensorily, there was no discernible difference between the two cocoa soda drinks produced. Both beverages scored slightly higher on the hedonic scale of acceptance. However, if chosen for commercialization in the food industry, a carbonated cocoa drink containing 10 grams of cocoa pulp is recommended. Microbial growth was $10^{-3} \mathrm{CFU} / \mathrm{g}$ in dry and fermented beans. $\mathrm{CO}_{2}$ gas dissolved in carbonated beverages and imparting a distinct flavor. Gases also contribute to the inhibition and eradication of pathogenic bacteria [58].

\subsection{Marmalade}

Marmalade is a fruit-based processed product. According to the Food Standards Agency [59], it is a mixture of water, sugar, fruit flesh, fruit puree, fruit juice, fruit peel, fruit juice extract, or a combination of these ingredients that forms a consistent gel. Marmalade is typically made with citrus fruit and long-term stability. High sugar and pectin content and low acid content are desirable fruit characteristics for its product. Pectin is a hydrophilic charged biopolymer. Pectin's gelling properties are due to its ability to form a three-dimensional network through chain cross-linking. Water cannot move freely in this hydrophilic network to a certain extent. It must avoid excessive dissociation of the carboxyl group to induce cross-linking. Increased acidity suppresses dissociation.

Additionally, a low $\mathrm{pH}$ can help prevent sucrose crystallization in marmalade products during storage. Increased $\mathrm{pH}$ values can result in the contraction of the pectin network and the release of fluid (syneresis). Sugar is necessary for flavor and for forming a fairly hard gel due to its water-binding properties. Additionally, sugar's reduction of water activity is critical for preservation [60].

Anvoh et al. [13] investigated the process of making marmalade from the cocoa pulp. Cocoa pulp sap has a $\mathrm{pH}$ of 3.14 and a high glucose concentration of $214.2 \mathrm{~g} / \mathrm{L}$. The resulting marmalade product exhibits characteristics like commercial apricot marmalade. Jams should have a pH of 2.8 
Rossi Indiarto et al., International Journal of Emerging Trends in Engineering Research, 9(8), August 2021, 1162 - 1169

to 3.5 , and marmalade should have a total dissolved solids content of 65 to $68^{\circ}$ Brix [60].

\subsection{Vinegar}

Vinegar gives foods such as sauces and mayonnaise a sensory flavor and aroma, apart from its use as a food additive. It can use to preserve fruits and vegetables. The acetic acid in natural vinegar contains acetoin, diacetyl, ethanol, and several different acetic esters [49]. One can make vinegar from synthetic or natural compounds derived from coconut water, apples, beets, pineapples, and even cocoa pulp liquid. Cocoa pulp liquid contains acetic acid, lactic acid, alcohol, and sugar, allowing it to be processed into vinegar. Ganda-Putra et al. [49] used three different fermentation methods: one-phase acetic acid fermentation, two-phase alcoholic and acetic acid fermentation, and natural aerobic fermentation without inoculum or carbon sources.

The vinegar produced contains a high concentration of acetic acid (1.64\%), propionic acid, total dissolved solids $(0.09 \%$ Brix), and sugar $(0.06 \%)$, all of which are obtained using the phase 1 fermentation method with the addition of $10 \%$ alcohol. However, this vinegar product contains a trace of salt $(0.01 \%)$ and low acidity (pH 2.53$)$. While adding $10 \%$ alcohol can increase the concentration of acetic acid, increasing the concentration of certain alcohols inhibits the growth of Acetobacter aceti bacteria, lowering the acid content. So, the optimal concentration of alcohol to use is $5-7 \%$. This study found that cocoa pulp liquid may be utilized as a raw material for vinegar manufacture, although further fermentation is necessary to maximize acetic acid synthesis. Table 2. summarizes the formula for cocoa pulp-based ingredients and their application to food products.

Table 2. Cocoa pulp-based ingredients and their food applications

\begin{tabular}{|c|c|c|}
\hline Ingredients formula & Application & Ref. \\
\hline Cacao pulp-pineapple juice & $\begin{array}{l}\text { Fortification of juices } \\
\text { with nutrients, } \\
\text { particularly Vit. C }\end{array}$ & [46] \\
\hline Cocoa pulp and kefir & $\begin{array}{l}\text { Cocoa pulp-based } \\
\text { kefir beverages }\end{array}$ & [47] \\
\hline $\begin{array}{l}\text { Cocoa pulp, sucrose } \\
\text { solution, calcium carbonate }\end{array}$ & Cocoa pulp wine & [48] \\
\hline $\begin{array}{l}\text { Cocoa pulp, cocoa liquor, } \\
\text { sugar }\end{array}$ & Cocoa marmalade & [13] \\
\hline $\begin{array}{lr}\text { Pasteurized } & \text { cocoa pulp } \\
\text { liquid, } & \text { Saccharomyces } \\
\text { cerevisiae } & \text { inoculum, } \\
\text { Acetobacter } & \text { aceti inoculum, } \\
\text { alcohol } & \end{array}$ & Cocoa vinegar & [49] \\
\hline $\begin{array}{l}\text { Cocoa pulp, cocoa liquor, } \\
\text { carbon dioxide }\end{array}$ & $\begin{array}{l}\text { Carbonated } \\
\text { beverages }\end{array}$ & [57] \\
\hline
\end{tabular}

\section{COCOA BEAN SHELL}

Cocoa bean shell is a by-product of cocoa bean that has nutritional and bio-functional potential [61]. These shells are high in cellulose lignin and can be used as dietary fiber [62].
Additionally, it has a significant amount of protein, fat, and carbs compared to other cocoa by-products. The protein content of the cocoa bean shell ranges from 10.30 to $27.40 \%$ [63]. It also contains bioactive components like polyphenols that serve as antioxidants. [64], [65].

Climate, cocoa variety, and processing variables such as fermentation, roasting, and temperature affect cocoa bean shell quality [66]. Hygroscopicity is also a property of these shells. Assume that the cocoa bean shell is stored in a humid environment. The shells will become infested with fungi or mycotoxin such as Aspergillus and also contaminating during the fermentation, roasting, and drying processes, among other processes. It can make efforts to avoid the growth of mycotoxins through proper storage, which inhibits the growth of fungi or mycotoxins on the cocoa bean skin.

The cocoa bean shell has a fat content ranging from 1.50 to $8.49 \%$. Roasting reduces fat content in cocoa bean skin. Some of the fatty acids found in cocoa bean shells include oleic, palmitate, capric, and stearic acids [67]. Cocoa bean shells are also high in antioxidants. Using the extraction method may be utilized in the food sector as a dietary supplement or flavoring for cakes and biscuits [68]. It may utilize cocoa bean shells' chemical and physical characteristics to create materials by integrating them into bioplastics to achieve antioxidant properties, biodegradability, and enhanced physicochemical properties [69]. Cocoa bean shells have antioxidant properties that can counteract oxidative effects. It is due to polyphenols in the cocoa bean shell, such as epicatechin, catechin, and procyanidin, which are antioxidant-rich compounds [64], [65], [70]. Renewable energy in cocoa bean shells is the latest innovation to make cocoa a valuable product and its potential for food applications.

\section{CONCLUSION}

Cocoa by-products are generated during the processing of cocoa beans. Most cocoa pods' by-products comprise pod husks, pulps, and bean shells. The three by-products produced are classified as waste that can pollute the environment or spread diseases to other plants. Cocoa pods can be used as dietary fiber, antiwrinkle cosmetics and preservatives, animal feed, organic fertilizers, paper-making materials, and biofuels. The cocoa pulp can make mixed drinks, kefir drinks, wine, and other products such as marmalade and vinegar-one of the latest innovations in research on renewable energy for cocoa bean shells.

\section{ACKNOWLEDGEMENT}

The authors would like to thank Universitas Padjadjaran and the Ministry of Education, Culture, Research, and Technology of the Republic of Indonesia for providing the research grants (number: 1207/UN6.3.1/PT.00/2021).

\section{REFERENCES}

[1] O. Rojo-Poveda, L. Barbosa-Pereira, G. Zeppa, and C. Stévigny, "Cocoa bean shell-a by-product with nutritional properties and biofunctional potential," 
Rossi Indiarto et al., International Journal of Emerging Trends in Engineering Research, 9(8), August 2021, 1162 - 1169

Nutrients, vol. 12, no. 4, pp. 1-29, 2020, doi: 10.3390/nu12041123.

[2] J. Panak Balentić et al., "Cocoa Shell: A By-Product with Great Potential for Wide Application," Molecules, vol. 23, no. 6, pp. 1-14, 2018, doi: $10.3390 /$ molecules23061404.

[3] R. Ravindran and A. K. Jaiswal, "Exploitation of Food Industry Waste for High-Value Products.," Trends Biotechnol., vol. 34, no. 1, pp. 58-69, Jan. 2016, doi: 10.1016/j.tibtech.2015.10.008.

[4] H. K. Biesalski et al., "Bioactive compounds: Definition and assessment of activity," Nutrition, vol. 25, no. 11-12, pp. 1202-1205, 2009, doi: 10.1016/j.nut.2009.04.023.

[5] K. P. Prabhakaran Nair, The Agronomy and Economy of Important Tree Crops of the Developing World. Elsevier Ltd, 2010.

[6] R. Martínez, P. Torres, M. A. Meneses, J. G. Figueroa, J. A. Pérez-Álvarez, and M. Viuda-Martos, "Chemical, technological and in vitro antioxidant properties of cocoa (Theobroma cacao L.) co-products," Food Res. Int., vol. 49, no. 1, pp. 39-45, 2012, doi: 10.1016/j.foodres.2012.08.005.

[7] V. T. T. Ho, J. Zhao, and G. Fleet, "Yeasts are essential for cocoa bean fermentation," Int. J. Food Microbiol., vol. 174, pp. 72-87, Mar. 2014, doi: 10.1016/j.ijfoodmicro.2013.12.014.

[8] G. Afrane and A. Ntiamoah, "Use of Pesticides in the Cocoa Industry and Their Impact on the Environment and the Food Chain," Pestic. Mod. World - Risks Benefits, 2011, doi: 10.5772/17921.

[9] J. C. Hashimoto et al., "Quality Control of Commercial Cocoa Beans (Theobroma cacao L.) by Near-infrared Spectroscopy," Food Anal. Methods, vol. 11, no. 5, pp. 1510-1517, 2018, doi: 10.1007/s12161-017-1137-2.

[10] E. O. K. Oddoye, C. K. Agyente-Badu, and E. Gyedu-Akoto, "Cocoa and its by-products: Identification and utilization," in Chocolate in Health and Nutrition, 2013, pp. 23-37.

[11] R. Campos-Vega, K. H. Nieto-Figueroa, and B. D. Oomah, "Cocoa (Theobroma cacao L.) pod husk: Renewable source of bioactive compounds," Trends Food Sci. Technol., vol. 81, no. September, pp. 172-184, 2018, doi: 10.1016/j.tifs.2018.09.022.

[12] D. S. Nielsen, O. D. Teniola, L. Ban-Koffi, M. Owusu, T. S. Andersson, and W. H. Holzapfel, "The microbiology of Ghanaian cocoa fermentations analysed using culture-dependent and culture-independent methods," Int. J. Food Microbiol., vol. 114, no. 2, pp. 168-186, Mar. 2007, doi: 10.1016/j.ijfoodmicro.2006.09.010.

[13] K. Y. B. Anvoh, A. Z. Bi, and D. Gnakri, "Production and characterization of juice from mucilage of cocoa beans and its transformation into marmalade," Pakistan J. Nutr., vol. 8, no. 2, pp. 129-133, 2009, doi: 10.3923/pjn.2009.129.133.

[14] L. C. Vriesmann, R. D. de Mello Castanho Amboni, and
C. L. De Oliveira Petkowicz, "Cacao pod husks (Theobroma cacao L.): Composition and hot-water-soluble pectins," Ind. Crops Prod., vol. 34, no. $1, \quad$ pp. 1173-1181, Jul. 2011, doi: 10.1016/j.indcrop.2011.04.004.

[15] F. Lu et al., "Valorisation strategies for cocoa pod husk and its fractions," Curr. Opin. Green Sustain. Chem., vol. 14, pp. 80-88, 2018, doi: 10.1016/j.cogsc.2018.07.007.

[16] E. Gyedu-Akoto, D. Yabani, J. Sefa, and D. Owusu, "Natural Skin-care Products: The Case of Soap Made from Cocoa Pod Husk Potash," Adv. Res., vol. 4, no. 6, pp. 365-370, 2015, doi: 10.9734/air/2015/17029.

[17] D. Mansur, T. Tago, T. Masuda, and H. Abimanyu, "Conversion of cacao pod husks by pyrolysis and catalytic reaction to produce useful chemicals," Biomass and Bioenergy, vol. 66, no. November 2017, pp. 275-285, 2014, doi: 10.1016/j.biombioe.2014.03.065.

[18] O. I. R and A. O. A, "Bioprocess systems applied for the production of bio-ethanol from lignocellulosic biomass of cocoa pod husk (Theobroma cacao L.) and other agricultural residues: A review," African J. Biotechnol., vol. 12, no. 35, pp. 5375-5388, 2013, doi: 10.5897/ajb2013.12890.

[19] B. M. Yapo, V. Besson, B. B. Koubala, and K. L. Koffi, "Adding Value to Cacao Pod Husks as a Potential Antioxidant-Dietary Fiber Source," Am. J. Food Nutr., vol. 1, no. 3, pp. 38-46, 2013, doi: 10.12691/ajfn-1-3-4.

[20] A. A. Sundarraj and T. V. Ranganathan, "A Review -Pectin from Agro and Industrial Waste," Int. J. Appl. Environ. Sci. ISSN, vol. 12, no. 10, pp. 973-6077, 2017, [Online]. Available: http://www.ripublication.com.

[21] O. Adi-Dako, K. Ofori-Kwakye, S. Frimpong Manso, M. EL Boakye-Gyasi, C. Sasu, and M. Pobee, "Physicochemical and Antimicrobial Properties of Cocoa Pod Husk Pectin Intended as a Versatile Pharmaceutical Excipient and Nutraceutical," $J$. Pharm., vol. 2016, pp. 1-12, 2016, doi: $10.1155 / 2016 / 7608693$.

[22] G. S. Hutomo, A. Rahim, and S. Kadir, "Pectin Isolation from Dry Pod Husk Cocoa with Hydrochloride Acid," Int. J. Curr. Microbiol. Appl. Sci., vol. 5, no. 11, pp. 751-756, 2016, doi: 10.20546/ijcmas.2016.511.086.

[23] K. E. Bach Knudsen, "The nutritional significance of 'dietary fibre' analysis," Anim. Feed Sci. Technol., vol. 90, no. 1-2, pp. 3-20, Mar. 2001, doi: 10.1016/S0377-8401(01)00193-6.

[24] I. Z. Amir, H. S. Hanida, and A. Syafiq, "Development and physical analysis of high fiber bread incorporated with cocoa (Theobroma cacao sp.) pod husk powder," Int. Food Res. J., vol. 20, no. 3, pp. 1301-1305, 2013.

[25] A. Quiles, G. M. Campbell, S. Struck, H. Rohm, and I. Hernando, "Fiber from fruit pomace: A review of applications in cereal-based products," Food Rev. Int., vol. 34, no. 2, pp. 162-181, 2018, doi: 10.1080/87559129.2016.1261299.

[26] M. R. Kosseva, "Functional food and nutraceuticals 
Rossi Indiarto et al., International Journal of Emerging Trends in Engineering Research, 9(8), August 2021, 1162 - 1169

derived from food industry wastes," in Food Industry Wastes, USA: Elsevier, 2013, pp. 103-120.

[27] L. Valadez-Carmona et al., "Effects of microwaves, hot air and freeze-drying on the phenolic compounds, antioxidant capacity, enzyme activity and microstructure of cacao pod husks (Theobroma cacao L.)," Innov. Food Sci. Emerg. Technol., vol. 41, pp. 378-386, 2017, doi: 10.1016/j.ifset.2017.04.012.

[28] A. Abdul Karim et al., "Efficacy of cocoa pod extract as antiwrinkle gel on human skin surface," J. Cosmet. Dermatol., vol. 15, no. 3, pp. 283-295, Sep. 2016, doi: 10.1111/jocd.12218.

[29] S. A. Adeyeye, S. O. Ayodele, O. D. Oloruntola, and J. O. Agbede, "Processed cocoa pod husk dietary inclusion: effects on the performance, carcass, haematogram, biochemical indices, antioxidant enzyme and histology of the liver and kidney in broiler chicken," Bull. Natl. Res. Cent., vol. 43, no. 1, p. 54, 2019, doi: 10.1186/s42269-019-0096-8.

[30] F. Alemawor, V. P. Dzogbefia, E. O. K. Oddoye, and J. H. Oldham, "Enzyme cocktail for enhancing poultry utilisation of cocoa pod husk," Sci. Res. Essays, vol. 4, no. 6, pp. 555-559, 2009.

[31] M. Barrera, M. Cervantes, W. C. Sauer, A. B. Araiza, N. Torrentera, and M. Cervantes, "Ileal amino acid digestibility and performance of growing pigs fed wheat-based diets supplemented with xylanase," $J$. Anim. Sci., vol. 82, no. 7, pp. 1997-2003, Jul. 2004, doi: $10.2527 / 2004.8271997 x$.

[32] E. B. Laconi and A. Jayanegara, "Improving nutritional quality of cocoa pod (Theobroma cacao) through chemical and biological treatments for ruminant feeding: In vitro and in vivo evaluation," Asian-Australasian J. Anim. Sci., vol. 28, no. 3, pp. 343-350, Mar. 2015, doi: 10.5713/ajas.13.0798.

[33] B. Çalişkan and A. C. Çalişkan, "Potassium Nutrition in Plants and Its Interactions with Other Nutrients in Hydroponic Culture," Potassium - Improv. Qual. Fruits Veg. Through Hydroponic Nutr. Manag., 2018, doi: 10.5772/intechopen.71951.

[34] C. Aboyeji, T. Olofintoye, O. Olaleye, O. Olugbemi, and O. Adetula, "Influence of Cocoa Pod Husk Powder on the Performance of Black Benniseed under Basal Application Phosphorus Fertilizer in the Southern Guinea Savannah of Nigeria," Adv. Environ. Biol., vol. 10, no. 7, pp. 78-84, Nov. 2016.

[35] L. S. Ayeni and O. State, "Integrated Application of Cocoa Pod Ash and NPK Fertilizer : Effect on soil and Plant Nutrient Status and Maize Performance - Field," vol. 6, no. 6, pp. 96-102, 2010.

[36] J. Shakhes, M. A. B. Marandi, F. Zeinaly, A. Saraian, and T. Saghafi, "Tobacco residuals as promising lignocellulosic materials for pulp and paper industry," BioResources, vol. 6, no. 4, pp. 4481-4493, 2011, doi: 10.15376/biores.6.4.4481-4493.

[37] M. Judt, "Non-wood plant fibres, will there be a come-back in paper-making?," Ind. Crops Prod., vol. 2, pp. 51-57, 1993.

[38] S. T. Thomsen, Z. Kádár, and J. E. Schmidt, "Compositional analysis and projected biofuel potentials from common West African agricultural residues," Biomass and Bioenergy, vol. 63, pp. 210-217, 2014, doi: 10.1016/j.biombioe.2014.01.045.

[39] S. Chen, X. Zhang, D. Singh, H. Yu, and X. Yang, "Biological pretreatment of lignocellulosics: Potential, progress and challenges," Biofuels, vol. 1, no. 1, pp. 177-199, Jan. 2010, doi: 10.4155/bfs.09.13.

[40] A. O. Akinola, J. F. Eiche, P. O. Owolabi, and A. P. Elegbeleye, "Pyrolytic analysis of cocoa pod for biofuel production," Niger. J. Technol., vol. 37, no. 4, p. 1026, 2018, doi: 10.4314/njt.v37i4.23.

[41] L. F. Ballesteros, M. Michelin, A. A. Vicente, J. A. Teixeira, and M. Â. Cerqueira, "Functional Properties of Lignocellulosic Materials," no. Chen 2014, pp. 35-47, 2018, doi: 10.1007/978-3-319-92940-8_3.

[42] V. K. Thakur and M. K. Thakur, "Recent advances in green hydrogels from lignin: A review," Int. J. Biol. Macromol., vol. 72, pp. 834-847, Jan. 2015, doi: 10.1016/j.ijbiomac.2014.09.044.

[43] B. Abdullah, S. A. F. A. S. Muhammad, and N. A. N. Mahmood, "Production of Biofuel via Hydrogenation of Lignin from Biomass," New Adv. Hydrog. Process. Fundam. Appl., 2017, doi: 10.5772/66108.

[44] A. I. Akinjokun, L. F. Petrik, A. O. Ogunfowokan, J. Ajao, and T. V. Ojumu, "Isolation and characterization of nanocrystalline cellulose from cocoa pod husk $(\mathrm{CPH})$ biomass wastes," Heliyon, vol. 7, no. 4, p. e06680, 2021, doi: 10.1016/j.heliyon.2021.e06680.

[45] S. N. H. M. Azmin, N. A. B. M. Hayat, and M. S. M. Nor, "Development and characterization of food packaging bioplastic film from cocoa pod husk cellulose incorporated with sugarcane bagasse fibre," $J$. Bioresour. Bioprod., vol. 5, no. 4, pp. 248-255, 2020, doi: 10.1016/j.jobab.2020.10.003.

[46] M. O. Afolabi, W. O. Ibitoye, and A. F. Agbaje, "Evaluation of Nutritional and Sensory Properties of Cocoa Pulp Beverage Supplemented with Pineapple Juice," J. Food Res., vol. 4, no. 6, p. 58, 2015, doi: $10.5539 /$ jfr.v4n6p58.

[47] C. Puerari, K. T. Magalhães, and R. F. Schwan, "New cocoa pulp-based kefir beverages: Microbiological, chemical composition and sensory analysis," Food Res. Int., vol. 48, no. 2, pp. 634-640, 2012, doi: 10.1016/j.foodres.2012.06.005.

[48] W. F. Duarte, D. R. Dias, J. M. Oliveira, J. A. Teixeira, J. B. de Almeida e Silva, and R. F. Schwan, "Characterization of different fruit wines made from cacao, cupuassu, gabiroba, jaboticaba and umbu," LWT - Food Sci. Technol., vol. 43, no. 10, pp. 1564-1572, 2010, doi: 10.1016/j.lwt.2010.03.010.

[49] G. P. Ganda-Putra, N. M. Wartini, and L. P. T. Darmayanti, "Characteristics of cocoa vinegar from pulp liquids fermentation by various methods," in AIP Conference Proceedings, 2019, vol. 2155, doi: 
Rossi Indiarto et al., International Journal of Emerging Trends in Engineering Research, 9(8), August 2021, 1162 - 1169

$10.1063 / 1.5125542$.

[50] B. C. T. Bourrie, B. P. Willing, and P. D. Cotter, "The microbiota and health promoting characteristics of the fermented beverage kefir," Front. Microbiol., vol. 7, no. MAY, p. 647, 2016, doi: 10.3389/fmicb.2016.00647.

[51] H. Radhouani, C. Gonçalves, F. R. Maia, J. M. Oliveira, and R. L. Reis, "Biological performance of a promising Kefiran-biopolymer with potential in regenerative medicine applications: a comparative study with hyaluronic acid," J. Mater. Sci. Mater. Med., vol. 29, no. 8, p. 124, 2018, doi: 10.1007/s10856-018-6132-7.

[52] B. Nielsen, G. C. Gürakan, and G. Ünlü, "Kefir: A Multifaceted Fermented Dairy Product," Probiotics Antimicrob. Proteins, vol. 6, no. 3-4, pp. 123-135, 2014, doi: 10.1007/s12602-014-9168-0.

[53] R. S. Hamida, A. Shami, M. A. Ali, Z. N. Almohawes, A. E. Mohammed, and M. M. Bin-Meferij, "Kefir: A protective dietary supplementation against viral infection," Biomed. Pharmacother., vol. 133, p. 110974, 2021, doi: 10.1016/j.biopha.2020.110974.

[54] J. Bakker and R. J. Clarke, "Volatile Components," Wine Flavour Chemistry. pp. 155-238, Nov. 09, 2011, doi: 10.1002/9781444346022.ch4.

[55] A. D. Coulter, P. W. Godden, and I. S. Pretorius, "Succinic acid - How it is formed, what is its effect on titratable acidity, and what factors influence its concentration in wine?," Aust. New Zeal. Wine Ind. J., vol. 19, no. 6, pp. 16-25, 2005.

[56] P. H. C. Randall et al., "Beverages , Nonalcoholic," Ulmann's Encycl. Ind. Chem., vol. 5, p. 419, 2012, doi: 10.1002/14356007.a04.

[57] M. Escalante, N. Badrie, and Bekele F.L., "Production and quality characterization of pulp from cocoa beans from Trinidad: effects of varying levels of pulp on value-added carbonated cocoa beverages," Agribus. Essent. Food Secur. Empower. Youth Enhancing Qual. Prod., vol. XLIX, pp. 279-296, 2013, doi: 10.13140/RG.2.1.2869.1362.

[58] D. Kregiel, "Health safety of soft drinks: Contents, containers, and microorganisms," Biomed Res. Int., vol. 2015, p. 128697, 2015, doi: 10.1155/2015/128697.

[59] Food Standard Agency, "The Jam and Similar Products Regulations 2003 Guidance Notes," 2005. [Online]. Available: http://www.food.gov.uk/sites/default/files/multimedia/ pdfs/jamregguid_rev.pdf.

[60] B. Wolf, "Confectionery and Sugar-Based Foods," Ref. Modul. Food Sci., pp. 1-4, 2016, doi: 10.1016/b978-0-08-100596-5.03452-1.

[61] I. L. Kayaputri, D. M. Sumanti, M. Djali, R. Indiarto, and D. L. Dewi, "Kajian Fitokimia Ekstrak Kulit Biji Kakao (Theobroma cacao L.)," Chim. Nat. Acta, vol. 2 , no. 1, pp. 83-90, 2014, doi: 10.24198/cna.v2.n1.9140.

[62] Z. S. Vásquez et al., "Biotechnological approaches for cocoa waste management: A review," Waste Manag., vol. 90, pp. 72-83, 2019, doi: 10.1016/j.wasman.2019.04.030.
[63] D. C. G. Okiyama, I. D. Soares, T. A. Toda, A. L. Oliveira, and C. E. C. Rodrigues, "Effect of the temperature on the kinetics of cocoa bean shell fat extraction using pressurized ethanol and evaluation of the lipid fraction and defatted meal," Ind. Crops Prod., vol. 130, no. September 2018, pp. 96-103, 2019, doi: 10.1016/j.indcrop.2018.12.063.

[64] R. Indiarto, Y. Pranoto, U. Santoso, and . S., "Evaluation of Physicochemical Properties and Antioxidant Activity of Polyphenol-Rich Cacao Bean Extract Through Water Blanching," Pakistan J. Nutr., vol. 18, no. 3, pp. 278-287, 2019, doi: 10.3923/pjn.2019.278.287.

[65] R. Indiarto, Y. Pranoto, U. Santoso, and Supriyanto, "In vitro antioxidant activity and profile of polyphenol compounds extracts and their fractions on cacao beans," Pakistan J. Biol. Sci., vol. 22, no. 1, pp. 34-44, 2019, doi: 10.3923/pjbs.2019.34.44.

[66] D. Diomande et al., "Multi-element, multi-compound isotope profiling as a means to distinguish the geographical and varietal origin of fermented cocoa (Theobroma cacao L.) beans," Food Chem., vol. 188, pp. 576-582, 2015, doi: 10.1016/j.foodchem.2015.05.040.

[67] F. A. González-Alejo, J. Barajas-Fernández, M. de los Á. Olán-Acosta, L. M. Lagunes-Gálvez, and P. García-Alamilla, "Supercritical fluid extraction of fat and caffeine with theobromine retention in the cocoa shell," Processes, vol. 7, no. 6, pp. 1-13, 2019, doi: 10.3390/PR7060385.

[68] C. Collar, C. M. Rosell, B. Muguerza, and L. Moulay, "Breadmaking performance and keeping behavior of cocoa-soluble fiber-enriched wheat breads," Food Sci. Technol. Int., vol. 15, no. 1, pp. 79-87, 2009, doi: $10.1177 / 1082013208102643$.

[69] T. N. Tran et al., "Bioelastomers Based on Cocoa Shell Waste with Antioxidant Ability," Adv. Sustain. Syst., vol. 1, no. 7, pp. 1-11, 2017, doi: 10.1002/adsu.201700002.

[70] R. R. Utami, R. Armunanto, S. Rahardjo, and Supriyanto, "Effects of cocoa bean (Theobroma cacao L.) fermentation on phenolic content, antioxidant activity and functional group of cocoa bean shell," Pakistan J. Nutr., vol. 15, no. 10, pp. 948-953, 2016, doi: 10.3923/pjn.2016.948.953. 